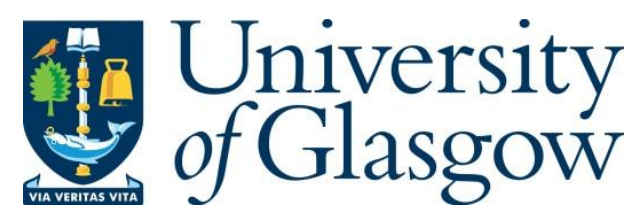

Liu, Y., Zhu, Q. and Seuring, S. (2017) Linking capabilities to green operations strategies: the moderating role of corporate environmental proactivity. International Journal of Production Economics, 187, pp. 182-195.

There may be differences between this version and the published version. You are advised to consult the publisher's version if you wish to cite from it.

http://eprints.gla.ac.uk/217986/

Deposited on: 12 June 2020

Enlighten - Research publications by members of the University of Glasgow http://eprints.gla.ac.uk 


\title{
Linking Capabilities to Green Operations Strategies: the moderating role of corporate environmental proactivity
}

\begin{abstract}
The aim of this study is to investigate the specific role of supply chain capabilities (SCCs) in the implementation of green operations (GO) strategies. More importantly, it examines whether this relationship between SCCs and GO is contingent on corporate environmental proactivity (EP). Theoretical predictions of the conceptual model were tested using hierarchical regression analyses of data obtained from 225 senior logistics/supply chain managers in the global auto sector. To ensure the robustness of our findings, a post-hoc analysis using the partial least squares approach was conducted. Significant positive associations exist between specific SCCs and the adoption of GO strategies. EP positively moderates the external integration capability green purchasing and the supplier appraisal capability - green manufacturing linkages. However, unexpectedly, EP negatively moderates the effect of internal integration capability on green purchasing. Equally surprising, consistent negative moderation effects are detected for supply chain flexibility on green design, green purchasing, and green manufacturing. This study contributes to the existing resource-based view literature by focusing on the capability - strategy linkage and its specific application to environmental management. The exploration of the moderating effects of EP confirms the important role of organizing context in the effective exploitation and deployment of resources and capabilities.
\end{abstract}

Keywords: Green operations, Supply chain capabilities, Resource-based view, Sustainability, Environmental management, Survey, Regression, Partial least squares, Automotive 


\section{Introduction}

The increasing need to address environmental issues surrounding business operations has gained enormous attention from both academics and practitioners, leading to the development of various green operations (GO) strategies, such as green design, green purchasing, green supply chains, and green manufacturing (Nunes and Bennett, 2010; Wong et al., 2012; Gimenez et al., 2012; Gavronski et al., 2012; Beske et al., 2014; Longoni et al., 2014). This is evident in a growing number of leading multi-national companies investing in GO, including PUMA's sustainable design and green packaging initiatives (PUMA, 2013), Unilever's sustainable sourcing (Unilever, 2014), and Mazda's green manufacturing programs (Mazda, 2014). These practical examples and the extant literature both support the assumption that GO can assist firms in gaining a first-mover advantage and achieving a long-term sustained competitive advantage (Zhu and Sarkis, 2004; Wong et al., 2012; Thoumy and Vachon, 2012; Figge and Hahn, 2012; Gimenez et al., 2012).

However, successfully adopting these green strategies is often a challenging task, particularly when firms are constrained by their limited resources and capabilities (Klassen and Whybark, 1999; Lee and Klassen, 2008; Wu and Pagell, 2011). To overcome the hurdles in green strategy implementation, organizations have started to develop complementary resources and capabilities with their network partners. For instance, to achieve sustainable innovation in its product development, Unilever collaborates with its partners to leverage the skills, capabilities, and network it lacks (Unilever, 2014). Similarly, by building strong relationships with suppliers, engaging strategic suppliers, and developing shared commitment and supplier capability, Ford is able to improve its capability to encourage and influence the sustainability goals and management processes of its suppliers, thereby helping to achieve its own sustainable objectives (Ford, 2014). 
Drawing on the resource-based view (RBV) (Wernerfelt 1984), prior research has argued that the choice of a corporate strategy should be supported by specific organizational capabilities to achieve intended performance (e.g., Gold et al., 2010; Morash, 2001; Beske et al., 2014). However, according to recent reviews of empirical research on the RBV of the firm, the associations between capability and strategy have largely been neglected, with the majority of studies focusing on linking resources/capabilities to competitive advantages and/or performance (Armstrong and Shimizu, 2007; Newbert, 2007).

This study will address the following research questions: (a) Does the successful implementation of GO strategies require the support of specific logistics/supply chain management (SCM)related capabilities? (b) Is this capability - GO strategy linkage contingent on certain organizing contexts? To answer these questions, the auto sector was selected for our study, as automakers have rather complex supply networks and are often at the forefront of environmental management (Zhu et al., 2007), which could offer interesting insights related to this study's research objectives.

Owing to the level of complexity and worldwide expansion of its supply networks, the auto industry is often confronted with significant barriers and challenges to its environmental management (Thun and Müller, 2010; Xia and Tang, 2011). As Thun and Müller (2010) noted, these challenges may arise from a lack of eco-oriented partnerships with supply chain partners coupled with a lack of internal environmental commitment and cross-functional integration. The limited resources and capabilities of suppliers may also frequently hamper an effective response to the environmental pressures in the auto industry (Lee and Klassen, 2008; Oh and Rhee, 2010). Thus, based on practical examples and the RBV, we contend that the successful implementation of GO strategies requires auto firms to possess and deploy their specific supply chain capabilities 
(SCCs). SCCs are defined as the ability of a firm to identify, utilize, and assimilate both internal and external resources to facility the entire supply chain activities (Wu et al., 2006). SCCs are valuable, rare, imperfectly imitable, and non-substitutable (VRIN) (Barney, 1991), as they can deliver value to customers, are not equally distributed across competitors, and are sufficiently complex to avoid easy imitation (Olavarrieta and Ellinger, 1997).

Furthermore, the environmental commitment of a firm is believed to have great influence on its strategic decisions for competitive outcomes (González-Benito and González-Benito, 2005). Environmentally proactive firms may be more willing to deploy their resources and capabilities to launch green initiatives. In line with Newbert's (2007) organizing approach, we argue that corporate environmental proactivity (EP) is an important firm-level condition that may affect the effective exploitation of capabilities for successful GO strategy implementation.

Using data collected from the global auto sector, we empirically tested the interactions among SCCs, EP, and GO strategies. One significant contribution of this study is that it examines the capability - strategy link by explicating the effects of SCCs on the adoption of GO strategies in the auto sector. Most importantly, our introduction of EP as a crucial moderating construct in the linkage between SCCs and GO strategies distinguishes our contribution from previous research (e.g., Bowen et al., 2001).

This article includes six sections. After the introduction, section 2 discusses the theoretical foundations and our conceptual framework. In section 3, we introduce our research methodology for data collection and data analysis. Following section 3, the survey results are presented in section 4. In section 5, we discuss the findings from our analysis results. Section 6 concludes our study with the implications of the research findings and several research limitations. 


\section{Theory and Hypotheses}

\subsection{Green operations}

GO addresses how to integrate environmental considerations into operations management by analyzing the specific strategies of organizations in, for example, product development, product lifecycle management, manufacturing, and supply chain management (Wong et al., 2012; Gimenez et al., 2012; Gavronski et al., 2012; Beske et al., 2014; Longoni et al., 2014). GO involves several environmental management strategies, including green design, green purchasing, green manufacturing, reuse, and recycling (Gmelin and Seuring, 2014; Sarkis and Dhavale, 2015; Nunes and Bennett, 2010; Wong et al., 2012). Incorporating these environmental strategies into daily business operations can bring many benefits not only to the focal firms, but also to the partners in the network (Handfield et al., 2005). For example, green design is a strategy in which a firm seeks to differentiate itself from its rivals by offering eco-friendly products and services. Customers may be willing to pay premium prices for these products, which is a clear economic advantage both for the companies offering such products and for their suppliers, who may manufacture products with less harmful raw materials or in a more environmentally sound manner (Marchi et al., 2013). In this study, we examine three key GO strategies, as outlined in Table 1.

Table 1 Key Green Operations Strategies

\begin{tabular}{clll}
\hline Green strategies & Description & Exemplar practices & Exemplar Benefits \\
\hline Green design & Green design or eco-design is defined & - Design of products for & • Product/service \\
(GD) & as the systematic consideration of & reuse, recycle, recovery of & differentiation \\
& design performance with respect to & material, component parts & - Premium price \\
& environmental, health, safety, and & - Design of products for & • Enhanced green image \\
& sustainability objectives over the full & reduced consumption of & - Customer loyalty \\
& product and process life cycle. & material/energy & (Emmett and Sood, 2010; \\
& (Glantschnig, 1994; Handfield et al., & (Zhu and Sarkis, 2004; Zhu & Marchi et al., 2013) \\
& 2001) & et al., 2007) & \\
\hline
\end{tabular}




\begin{tabular}{|c|c|c|c|}
\hline $\begin{array}{c}\text { Green purchasing } \\
\text { (GP) }\end{array}$ & $\begin{array}{l}\text { Green purchasing/procurement refers to } \\
\text { the way in which innovations in supply } \\
\text { chain management and industrial } \\
\text { purchasing may be considered in the } \\
\text { context of the environment. It aims to } \\
\text { facilitate recycling, reuse, and resource } \\
\text { reduction. (Green et al., 1996; Min and } \\
\text { Galle, 1997; Blome et al., 2014) }\end{array}$ & $\begin{array}{l}\text { - Environmental audit for } \\
\text { suppliers' inner } \\
\text { management } \\
\text { - Green supplier } \\
\text { development } \\
\text { - Supplier ISO4000 series } \\
\text { certification } \\
\text { (Zhu et al., 2007; Blome et } \\
\text { al., 2014) }\end{array}$ & $\begin{array}{l}\text { - Cost savings (e.g. lower } \\
\text { waste management fees) } \\
\text { - Compliance with } \\
\text { environmental } \\
\text { regulations } \\
\text { - Reduced risk of } \\
\text { accidents, liabilities } \\
\text { (Emmett and Sood, 2010) }\end{array}$ \\
\hline $\begin{array}{c}\text { Green } \\
\text { manufacturing } \\
(\mathrm{GM})\end{array}$ & $\begin{array}{l}\text { The notion of green manufacturing is to } \\
\text { reduce the harmful environmental } \\
\text { impacts of manufacturing, including } \\
\text { minimization of environmental and } \\
\text { health risks, reduction of energy } \\
\text { consumption and emissions, } \\
\text { improvement of materials utilization } \\
\text { efficiency and enhancement of } \\
\text { operational efficiency. (Zhang et al., } \\
\text { 1997; Deif, 2011) }\end{array}$ & $\begin{array}{l}\text { - Environmental compliance } \\
\text { and auditing programs } \\
\text { - Total quality environmental } \\
\text { management } \\
\text { - ISO14000 series } \\
\text { certification } \\
\text { (Zhu and Sarkis, 2004; Zhu et } \\
\text { al., 2008) }\end{array}$ & $\begin{array}{l}\text { - Efficient and enhanced } \\
\text { internal processes } \\
\text { - Cost savings } \\
\text { - Improved market } \\
\text { opportunities } \\
\text { - Pre-empting regulation } \\
\text { - Reduced risk of } \\
\text { accidents, liabilities } \\
\text { (Emmett and Sood, 2010) }\end{array}$ \\
\hline
\end{tabular}

Despite these tangible and intangible benefits, the choice of GO strategies is often a complex issue and depends on a range of factors, such as firms' attitudes, competitive positioning, the structure of the industry, and the types of markets (Lee and Rhee, 2007). Given the high fragmentation of production networks and globalization, firms are confronted with the complexity of coordination due to increased distances and differences in business culture and environmental legislation. The more complex a firm's supply network is, the more the firm is compelled to shape its green strategies to reduce environmental problems (Marchi et al., 2013). Therefore, strategic decision-making in GO strategies becomes critically important and challenging, especially when firms are constrained by their limited resources and capabilities (Wu and Pagell, 2011). As Klassen and Johnson (2004) noted, the successful adoption of some of the green strategies might require the support of particular logistics/SCM-related resources and capabilities.

The auto sector has traditionally received considerable attention in the context of greening because of its pollution effects (van Hoek, 2001; Zhu et al., 2007). Therefore, many automakers 
have begun to implement various GO strategies to address the negative environmental impacts of automobile production. Examples include Toyota's eco-design initiatives, Volkswagen's green purchasing programs, and General Motors' green manufacturing (Nunes and Bennett, 2010). However, the auto industry is also confronted with significant barriers and challenges to its environmental management because of the level of complexity and worldwide expansion of its supply networks (Thun and Müller, 2010; Xia and Tang, 2011). For instance, Thun and Müller's (2010) study noted the need for both inter- and intra- firm resources for effective environmental management in the German automotive industry. In their study of the Australian automotive industry, Simpson et al. (2007) noted that buyer-supplier-relationship-specific investment could have a significant impact on the green supply commitment of suppliers. All of these studies have suggested the importance of having specific organizational resources and capabilities for successful environmental management in the auto industry.

\subsection{Supply chain capabilities}

In today's highly competitive environment, globalization, shifting channel power, and the increasing reliance on supply network relationships necessitate the use of logistics/SCM for enhanced competitiveness. Olavarrieta and Ellinger (1997) contended that logistics/SCM-related capabilities can be sources of sustained competitive advantage because they provide value to the

customer, are not equally distributed across competitors, and are sufficiently complex to avoid easy imitation. As Fawcett et al. (1997) noted, the importance of on-time delivery, unique service offerings, and cost efficiency in complex and dynamic networks all point to logistics/SCM processes that could, if properly managed, perform as critical capabilities.

Wu et al. (2006) conceptualized SCCs as "...the ability of an organization to identify, utilize, and assimilate both internal and external resources/information to facilitate the entire supply chain 
activities." By examining the existing literature on logistics capabilities, Esper et al. (2007) synthesized the most frequently discussed SCCs into five major categories: customer focus capability, supply management capability, integration capability, measurement capability, and information exchange capability. Following Esper et al. (2007), Defee and Fugate (2010) speculated that logistics/SCM capabilities can be classified into higher-order capabilities and lower-level functional capabilities. A higher-order (i.e., core/distinctive) logistics capability represents an amalgamation of the activities, processes, and outcomes associated with the firm's overall logistics operations. In contrast, a lower-order capability represents the functional decomposition of logistics, e.g., logistics information technology/system (IT/IS) capability. Gligor and Holcomb (2012) further contended that SCCs have both internal and external dimensions. Through effective coordination and cooperation, the lower-level capabilities could lead to integrated SCCs (i.e., higher-order/distinctive capabilities).

The RBV literature has noted that the implementation of strategies requires firms to possess appropriate resources and capabilities (Wernerfelt, 1984; Barney, 1991). SCCs are believed to support the implementation of supply chain-related strategies (e.g., lean and agile strategies) (Morash, 2001). Once these strategies are successfully implemented, they can help firms to achieve supply chain-related competitive advantages (Morash, 2001). Moreover, through the implementation of strategies, organizations may be able to develop higher-level/distinctive SCCs (e.g., a lean SCC), which are more valuable, rare and difficult to imitate and substitute (Gligor and Holcomb, 2012). Consequently, a sustained supply chain-related competitive advantage can be expected.

Similarly, we believe that the successful implementation of a green strategy requires the support of specific SCCs. For instance, if a firm decides to adopt a green design strategy to offer 
environmentally friendly products on the market, this may require the firm to work closely with its suppliers who can support new design initiatives. The firm may also need to deploy its SCM skills and knowledge to adapt to the new challenges inherent in sourcing and finding new, competent suppliers. Once a green design strategy is successfully adopted, the firm may be able to gain an environmentally competitive advantage by offering greener products on the market. On the other hand, by adopting a green design strategy, the firm may be able to gain a distinctive higher-order green design capability, which can offer the firm a sustained environmentally competitive advantage in the long run, as such a capability is rather difficult to acquire and imitate and is thus more valuable and rare (Shang et al., 2010).

Table 2 summarizes the six most critical SCCs from the relevant literature. These SCCs are considered lower-order functional capabilities. Although these SCCs can be developed in isolation, they are more likely to be mutually supportive (Kristal et al., 2010; Daugherty et al., 2009; Shang and Marlow, 2005). As Ralston et al. (2013) noted, whereas unique higher-order logistics capabilities have the potential to improve logistics performance, each lower-level capability should be analyzed on its own merits.

Table 2 Supply Chain Capabilities

\begin{tabular}{|c|c|c|}
\hline Key SCCs & Description & Contributing author(s) \\
\hline $\begin{array}{l}\text { Internal } \\
\text { integration }\end{array}$ & $\begin{array}{l}\text { The ability of a firm to establish liaison between its } \\
\text { logistics/SCM department and other functions to } \\
\text { work together in a cooperative manner to arrive at } \\
\text { mutually acceptable outcomes. }\end{array}$ & $\begin{array}{l}\text { Olavarrieta and Ellinger, 1997; Stank and } \\
\text { Lackey, 1997; Bowen et al., 2001; Cousins and } \\
\text { Menguc, 2006; Kim, 2006; Esper et al., 2007; } \\
\text { Daugherty et al., 2009; Defee and Fugate, 2010; } \\
\text { Lado et al., 2011; Gligor and Holcomb, 2012; } \\
\text { Leuschner et al., 2013; Mackelprang et al., 2014 }\end{array}$ \\
\hline $\begin{array}{l}\text { External } \\
\text { integration }\end{array}$ & $\begin{array}{l}\text { The ability of a firm to establish collaboration and } \\
\text { partnership with its supply chain members, which } \\
\text { can best be described as an inter-organizational } \\
\text { relationship type in which the participating parties } \\
\text { agree to invest resources, mutually achieve goals, } \\
\text { share information, resources, rewards, and } \\
\text { responsibilities as well as jointly make decisions }\end{array}$ & $\begin{array}{l}\text { Fawcett et al., 1997; Olavarrieta and Ellinger, } \\
\text { 1997; Stank and Lackey, 1997; Bowen et al., } \\
\text { 2001; Morash, 2001; Tracey et al., 2005; Cousins } \\
\text { and Menguc, 2006; Kim, 2006; Wu et al., 2006; } \\
\text { Rai et al., 2006; Esper et al., 2007; Defee and } \\
\text { Fugate, 2010; Lado et al., 2011; Parmigiani et al., } \\
\text { 2011; Gligor and Holcomb, 2012; Leuschner et }\end{array}$ \\
\hline
\end{tabular}


Supplier appraisal The ability of a firm's logistics/SCM department to develop sophisticated and robust supplier selection and evaluation procedure/system that enables the firm to find competent and qualified suppliers who can meet its performance objectives

SCM skills/knowledge

Supply chain flexibility

IT/IS support
The overall ability of a firm's logistics/SCM personnel (with their skills/knowledge) to effectively perform logistics/SCM activities and tasks, and to establish good working relationships both within the firm and with external supply chain partners.

The overall ability of a firm's supply chain to cope with uncertainties by adjusting its objectives, and to respond to the needs of its target market with the support of a system or network of interrelated external flexibility (inbound and outbound) and internal manufacturing flexibility.

The ability of a firm's logistics/SCM IT/IS system to acquire, process, and transmit consistent, timely and reliable supply chain-related information within and across its boundaries for effective decisionmaking.
Fawcett et al., 1997; Stank and Lackey, 1997; Bowen et al., 2001; Tracey et al., 2005; Esper et al., 2007; Parmigiani et al., 2011

Fawcett et al., 1997; Stank and Lackey, 1997; Bowen et al., 2001; Defee and Fugate, 2010; Parmigiani et al., 2011; Ralston et al., 2013

Fawcett et al., 1997; Stank and Lackey, 1997; Morash, 2001; Zhao et al., 2001; Zhang et al., 2002; Tracey et al., 2005; Shang and Marlow, 2005; Wu et al., 2006; Esper et al., 2007; Defee and Fugate, 2010; Gligor and Holcomb, 2012; Malhotra and Mackelprang, 2012

Fawcett et al., 1997; Stank and Lackey, 1997; Morash, 2001; Zhao et al., 2001; Tracey et al., 2005; Shang and Marlow, 2005; Rai et al., 2006; Esper et al., 2007; Daugherty et al., 2009; Defee and Fugate, 2010; Fawcett et al., 2011; Gligor and Holcomb, 2012

Internal integration (INTER). INTER can be a critical SCC for a firm to enhance joint problem solving and to facilitate cross-functional information and knowledge exchange. This capability may not be easily obtained, but once developed, it could ultimately help to improve customer satisfaction and supply chain performance (Eng, 2005). The recent meta-analyses conducted by Leuschner et al. (2013) and Mackelprang et al. (2014) further confirm the critical role of internal integration in improving firm performance. For example, Jassawalla and Sashittal (1999) studied cross-functional new product development teams in a high-technology industry and found that teams with collaborative behaviors could accelerate new product development processes compared with those that lacked a common agenda, shared concerns and power, and a commitment to building trust. Stronger internal integration may thus help the focal firm to 
overcome various hurdles and challenges in the adoption of GO strategies.

External integration (EXTER). An organization's ability to establish collaborative and partnering relationships with its supply chain members can bring many benefits compared to arms-length relationships, such as increased economic gains through extensive knowledge sharing and lowered transaction costs (Esper et al., 2007; Leuschner et al., 2013; Mackelprang et al., 2014). For instance, in a study of the automotive industry, Takeishi (2001) found that strong ties with automotive suppliers could enhance frequent communication, integrated problem solving, and knowledge sharing, which could significantly improve product design performance. We believe that a strong partnership and collaboration with supply chain partners could also enable the successful adoption of GO strategies.

Supplier appraisal (APRSL). In practice, many firms suffer from the poor performances of their suppliers, and the question of whether suppliers possess adequate resources and competences to perform certain tasks is of major concern for many purchasing managers (Modi and Mabert, 2007). This capability is thus vital to ensure the total competitiveness of the entire supply chain. An empirical study of American manufacturing firms undertaken by Kannan and Tan (2002) confirmed that effective supplier selection and evaluation could have a positive effect on business performance. A strong APRSL capability can potentially nurture strong ties, shared expectations, and objectives between a firm and its suppliers. The stronger this capability, the easier it may be for the firm to address supplier delivery and quality problems as well as GO initiatives.

SCM skills/knowledge (SKILL). SKILL are embedded in individuals and groups, making the process of learning, generating, and sharing them extremely complex (Kogut and Zander, 1992). 
Firms differ in their skills/knowledge, and these differences have enduring effects on their relative performances (ibid, 1992). SCM personnel's possession of excellent skills/knowledge can be an extremely valuable source of competitive advantages. For example, Lee et al. (2011) discovered that certain skills and knowledge (e.g., learning and information sharing abilities) among workers could ultimately affect performance in manufacturing process innovation projects, such as lean manufacturing, Six Sigma programs, new product introductions, and technology upgrades. As such, organizations that possess this capability may also find it easier to implement various GO strategies, especially in terms of handling the complexity and challenges inherent in various environmental management programs and technologies.

Supply chain flexibility (FLEXY). Teece and Pisano (1994) characterized firms that have honed in on this capability as "high flex." An empirical study conducted by Sánchez and Pérez (2005) indicated that FLEXY could positively affect a firm's performance. As Duclos et al. (2003) suggested, the benefit of FLEXY lies in the ability to facilitate the implementation of meaningful organizational strategies that satisfy customer demands and improve overall firm performance. We believe FLEXY can be a critical SCC that may facilitate GO strategies.

IT/IS support (IT/IS). IT/IS can also be a valuable SCC (Rai et al., 2006), through which information can be readily and continuously accessed, used, and shared across a supply chain (Bharadwaj et al., 2007). As Barney (1991) discussed, developing this capability requires the successful interweaving of IT/IS into existing business processes and practices, which can be highly complicated and difficult to achieve. However, once it is effectively developed, a competitive advantage can be expected. For instance, Wu et al. (2006) found that embedding IT into a firm's supply chain process could lead to enhanced firm performance. With strong IT/IS support, it is believed that GO strategies could be smoothly adopted. 


\subsection{Hypotheses development}

For a green design strategy, strong internal collaboration and the active involvement of the logistics/SCM department in the green design process can help the buying firm to find available environmentally friendly raw materials and components more efficiently. Similarly, external integration with suppliers may facilitate knowledge sharing and joint problem solving, where suppliers' technology and innovation capabilities can be brought into the design process to enhance green design performance. However, effective supplier selection must be supported by a well-developed supplier appraisal mechanism. The knowledge and information sharing activities may also be facilitated by effective and reliable IT/IS support. In order to rapidly introduce green products on the market in a cost-effective manner, the focal firm may also need a flexible supply chain to cope with the fast-changing demands and uncertainties in the market. For example, strong supply chain flexibility can enable the focal firm to cope with design changes (e.g., substitution with sustainable components/materials), network changes (e.g., quickly finding new and competent suppliers for new components), and volume changes in demand. We thus propose the following hypothesis:

H1: There is a positive relationship between supply chain capabilities and green design implementation.

Green purchasing is also a complex and challenging task, which considers not only traditional factors, such as a supplier's cost, quality, lead time, and flexibility, but also environmental responsibility (Lee et al., 2009). SCCs are thus proposed to enable the implementation of a green purchasing strategy. For example, Carter and Carter (1998) suggested that increased coordination - both within a firm and externally with suppliers and downstream members of the supply chain - could facilitate green purchasing initiatives. In addition, as Green et al. (1996) noted, firms that 
are good at supplier appraisal may find it easier to incorporate green factors into their purchasing strategies. Green purchasing also involves extensive supplier coaching, education, and mentoring. Therefore, the focal firm's logistics/purchasing team's skills and knowledge can improve the efficiency and effectiveness of such training and education programs. Greater supply flexibility often occurs as the number of qualified suppliers increases, enabling the buying firms to more easily find and select competent suppliers to realize their green purchasing strategy. Similarly, effective and reliable IT/IS support may enable effective green knowledge sharing and data exchange, thereby facilitating green purchasing. Thus, we propose:

H2: There is a positive relationship between supply chain capabilities and green purchasing implementation.

The successful adoption of a green manufacturing strategy is extremely challenging because it involves complex techniques and systems (Miller et al., 2010). Klassen (1993) argued that to successfully adopt a green manufacturing strategy, the manufacturing group must foster internal collaboration with other functional areas within a firm. Likewise, external integration with supply chain members could significantly affect both the level and the form of investment in green technologies in manufacturing (Klassen and Vachon, 2003). An adequate level of logistics/SCM skills and knowledge and an effective supplier appraisal system may enable the buying firm to find competent suppliers who can satisfy the requirements associated with a green manufacturing strategy. Supply chain flexibility could also ensure that suppliers can quickly adapt their production pace and output to satisfy the requirements imposed by the new green manufacturing agenda of their buying firms. As such, the focal firms can swiftly manufacture any new high-quality green products in a cost-effective manner. Finally, effective and reliable SCM IT/IS support can enable effective environmental monitoring and identification of 
problems in manufacturing (Melville, 2010). Therefore, we propose the following hypothesis:

H3: There is a positive relationship between supply chain capabilities and green manufacturing implementation.

We also believe that the hypothesized associations between SCCs and GO strategies might be contingent on certain organizing contexts. In light of Newbert's (2007) organizing approach, certain firm-level conditions enable the effective exploitation of resources and capabilities. For example, citing Barney's framework, Wiklund and Shepherd claimed that in addition to possessing VRIN resources and capabilities, companies must also possess an appropriate firmlevel condition to take advantage of such resources and capabilities (Newbert, 2007). They argued that a firm's entrepreneurial orientation is an organizing context and then tested the effect of the interaction between a firm's knowledge (a resource) and its entrepreneurial orientation on its financial and non-financial performance.

In this study, we argue that corporate environmental proactivity is an important firm-level condition that may affect the effective exploitation of SCCs for successful GO strategy implementation. The environmental commitment of firms has become a significant variable with respect to most of today's competitive scenarios (González-Benito and González-Benito, 2005). As a critical organizing context, Handfield et al. (1997) described six different modes of a firm's response to environmental issues, which range from "resistant adaptation" to "proactive" responses. Proactive firms internalize environmental challenges and optimize their processes to satisfy customer demand and handle environmental issues. Corporate EP may stem from top management's attitudes, commitment, and awareness of environmental rents. A proactive corporate environmental stance defines a situation in which firms extend their efforts beyond basic compliance with laws and environmental regulations (Aragón-Correa and Sharma, 2003). 
When firms demonstrate strong EP, they may be more likely to deploy and exploit their resources and capabilities toward the implementation of green strategies. As a result, the positive relationships between SCCs and the implementation of GO strategies might be amplified in those firms with a stronger EP orientation. For instance, an environmentally proactive firm that has strong integration and partnerships with its suppliers may be more willing to deploy and exploit this capability to foster inter-firm learning and engage in environmental collaboration to implement a green design strategy. Conversely, although they may possess strong capabilities, less proactive firms may be reluctant to fully deploy their resources and capabilities toward the adoption of green strategies; thus, the relationships between SCCs and GO strategies may not be amplified. Hence, we propose:

H4: Corporate environmental proactivity positively moderates the relationship between supply chain capabilities and (a) green design, (b) green purchasing, and (c) green manufacturing implementation.

Figure 1 below represents the conceptual model.

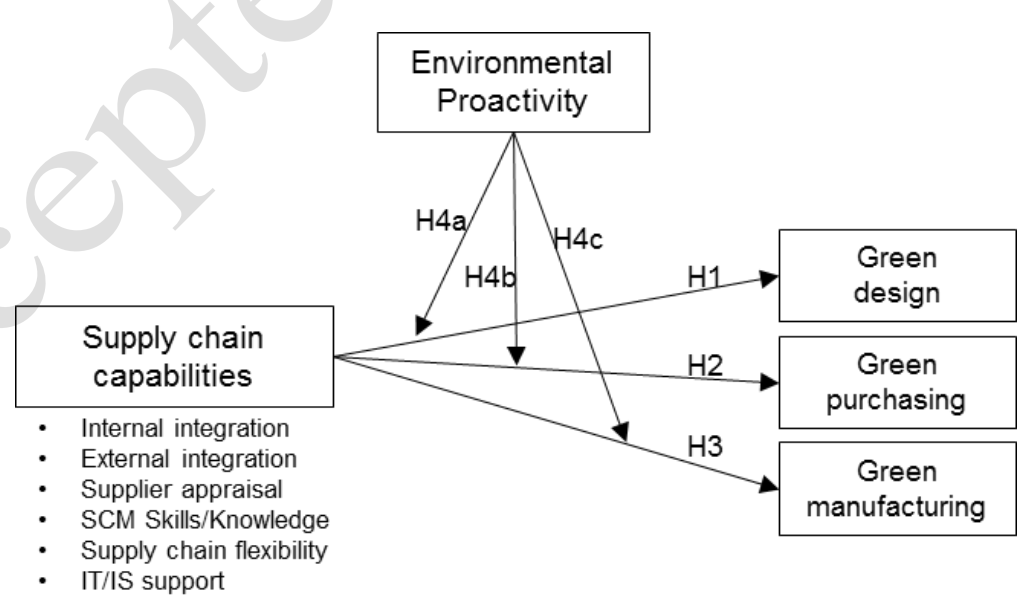

Figure 1 Conceptual Model 


\section{Methods}

\subsection{Questionnaire development}

To develop the questionnaire, we first conducted interviews with academics and industrial managers in the areas of logistics/SCM and environmental management. This step provided us with a preliminary understanding of logistics/SCM-related capabilities and current industry practices. We then developed a draft questionnaire with a pool of measurement items by consolidating the findings from the interviews and the literature. The third step involved pretesting the draft questionnaire with academics and practitioners in relevant fields to evaluate its clarity, utility, and relevancy. We combined or rephrased scale items and dropped irrelevant ones according to the feedback we received. The fourth step consisted of a pilot test with 20 supply chain/logistics managers in the automotive industry. The questionnaire was then further refined according to the comments received. The survey instrument was in both Chinese and English. To ensure consistency and measurement invariance, the translation was made and crosschecked by our research colleagues who are bilingual in English and Chinese.

Three items were used to measure our first independent variable (IV), internal integration (INTER). These scales were primarily based on prior work (e.g., Flynn et al., 2010; Schoenherr and Swink, 2012). The second IV measured the extent to which a firm was able to develop supplier appraisal (APRSL), as reflected by three items obtained from Spekman (1988), Choi and Hartley (1996), and Tracey and Tan (2001). For assessing external integration (EXTER), we adapted previously validated measures from Das et al. (2006), Cao and Zhang (2011), and Zhao et al. (2011). The scale for SCM skills/knowledge (SKILL) was obtained from Lee et al. (1995), Briscoe et al. (2001), Byrd and Turner (2001). The construct, supply chain flexibility (FLEXY), was based on previous research (Duclos et al., 2003; Vickery et al., 1999; Stevenson and Spring, 
2007). However, FLEXY is a rather complex multi-dimensional construct, and thus it would be impractical in this study to include all the dimensions under one construct. As suggested by the managers we interviewed and the extant literature, FLEXY should be viewed as an integrated capability and from the customer's perspective (e.g., Malhotra and Mackelprang, 2012). Thus, we used only three items to measure a firm's FLEXY. Our last IV, IT/IS support (IT/IS), was measured with three items, which were also derived from earlier studies (Sanders and Premus, 2005; Rai et al., 2006). A 5-point scale was used to capture the competency level of SCCs in each responding firm.

With respect to our dependent variables (DVs), we believed that the implementation of these green strategies would be reflected by the adoption of specific green practices in the responding firms. In particular, green design (GD) items were adapted from Zhu and Sarkis (2004) and Zhu et al. (2007). As suggested by the managers we interviewed, we included an additional item derived from Zhang et al. (1997) to measure product longevity and durability considerations in product design. Our measurement of the green purchasing (GP) construct was consistent with that used by Zhu et al. (2007). The items for measuring green manufacturing (GM) were taken from Zhu and Sarkis (2004) and Zhu et al. (2008). To measure DVs, we modified the 5-point scale used by Zhu and Sarkis (2004) by placing more emphasis on implementation (see Appendix).

Measurement of the EP construct was consistent with the items used by Bowen et al. (2001) and Simpson et al. (2007). Firm size, which was measured by the total number of employees, was introduced as a control variable in the analysis. This is because firm size may influence both the development of capabilities and the adoption of green strategies, thus confounding the studied relationships between the key constructs. Likewise, tier position within the supply network 
(measured in terms of a firm's main product in the auto sector) may also produce similar confounding effects, so we also controlled for supply chain tiers with two dummy variables in the study (Tier 2 as the baseline).

\subsection{Data collection}

Logistics/SCM managers served as key informants for this study. All the sample firms must meet three essential criteria: the major product of the firm serves the auto sector (which identifies the tier position of the firm in the automotive supply chain); the firm has been in existence for at least 5 years (and thus has developed a reasonable level of SCCs); and the firm should have certain environmental management systems in place (e.g., ISO14000 certification). To ensure the representativeness of our data (Fowler, 2009), we drew a random sample of 1,000 from the available nationwide databases (Automotive Industry Portal) that comprised approx. 40,000 entries (global suppliers and OEMs). The contact information was obtained through sector-based professional groups. The data were collected in early 2014 via an online form. After sending out an initial email and two follow-up reminders, which were spaced two weeks apart, we received 246 responses in total, out of which 225 were usable, resulting in an effective response rate of $22.5 \%$ (see Table 3 ).

Table 3 Distribution of Survey Respondents

\begin{tabular}{|c|c|c|}
\hline & Total & Percentage \\
\hline \multicolumn{3}{|l|}{ Region } \\
\hline China $(\mathrm{CN})$ & 108 & 48.0 \\
\hline North America (NA) & 48 & 21.3 \\
\hline Europe (EU) & 46 & 20.4 \\
\hline Other & 23 & 10.2 \\
\hline \multicolumn{3}{|l|}{ Supply Chain Position } \\
\hline OEM (automaker) & 64 & 28.4 \\
\hline Tier 1 supplier & 118 & 52.4 \\
\hline Tier 2 supplier & 43 & 19.1 \\
\hline \multicolumn{3}{|l|}{ Size (employees) } \\
\hline$<200$ & 32 & 14.2 \\
\hline $200-500$ & 22 & 9.8 \\
\hline $501-1000$ & 17 & 7.6 \\
\hline $1001-2000$ & 38 & 16.9 \\
\hline $2001-3000$ & 15 & 6.7 \\
\hline$>3000$ & 101 & 44.9 \\
\hline Total & 225 & 100 \\
\hline
\end{tabular}


Comparing respondents with non-respondents in terms of firm size (number of employees), supply chain position (main products) and their annual sales yielded no significant differences, indicating that these responses were representative of the original sample. Furthermore, we compared the early responses to those late responses along the main variables, based on the assumption that the opinions of late responders are very similar to those of non-respondents (Armstrong and Overton 1977). The results of t-tests revealed that the respondents did not differ significantly $(\mathrm{p}>.05)$. We can thus be reasonably confident that non-response bias was not a problem in our study.

\subsection{Preliminary test}

As the questionnaire was in Chinese and English, and the data were collected from multiple countries, measurement invariance is essential before conducting any further analysis. Due to the limited size of our data, we performed a two-group (Chinese vs. non-Chinese) invariance test with multi-group confirmatory factor analysis (CFA) (Steenkamp and Baumgartner, 1998) in IBM AMOS 22. First, we performed a configural invariance test consisting of the baseline models of Chinese and non-Chinese samples without imposing any equality constraints. Second, we tested metric invariance by constraining all free factor loadings to be equal across the two groups. As shown in Table 4, the goodness-of-fit results show that the models exhibit satisfactory fit to the data, and no significant increase between the configural invariance model and the metric invariance model invariance was found $\left(\Delta \chi^{2}=42, \mathrm{p}>.05\right)$. To test scalar invariance, we constrained all factor loadings and all observed variable intercepts. The full scalar invariance test did not return satisfactory results. Therefore, we refined our models by relaxing several items and achieved partial scalar invariance. Overall, the results of the invariance tests were acceptable for the aim of our study (Steenkamp and Baumgartner, 1998). 
Table 1 Measurement Invariance Test

\begin{tabular}{llllllllll}
\hline & $\chi^{2}$ value & $d f$ & $\mathrm{p}$-value & $\chi^{2} / d f$ & CFI & TLI & RMSEA & PCLOSE & $\Delta \chi^{2}$ test \\
\hline Configural invariance & 1871 & 1368 & .000 & 1.37 & 0.91 & 0.90 & 0.04 & 1.00 & - \\
Metric invariance & 1913 & 1397 & .000 & 1.37 & 0.91 & 0.90 & 0.04 & 1.00 & $\Delta \chi^{2}=42 ; \mathrm{p}>0.05$ \\
Scalar invariance & 2227 & 1426 & .000 & 1.56 & 0.86 & 0.84 & 0.05 & 0.46 & $\Delta \chi^{2}=356 ; \mathrm{p}<.001$ \\
Partial scalar invariance & 1912 & 1396 & .000 & 1.37 & 0.91 & 0.90 & 0.04 & 1.00 & $\Delta \chi^{2}=41 ; \mathrm{p}>0.05$ \\
\hline
\end{tabular}

To avoid/diminish the common method bias problem for self-reported data, we applied several procedures described by Podsakoff et al. (2003). To test for common method variance, Harman's single-factor test was performed. The factor analysis of all items revealed 10 factors with eigenvalues greater than 1.0 that accounted for $75 \%$ of the total variance. The first factor only accounted for $30 \%$ of the variance. These results indicate that common method bias was not a serious problem in this study (Hair et al., 2010).

Internal scale reliability was assessed with Cronbach's alpha. The $\alpha$ values for the constructs all exceeded the recommended threshold of .70 (Nunnally, 1978) (see Appendix). We used exploratory factor analysis (EFA) to assess groupings and the unidimensionality of the survey constructs. Factors were extracted using the maximum likelihood method and a varimax rotation. Only the factors with latent roots (eigenvalues) greater than 1 were considered significant (Hair et al., 2010). The factor analysis empirically grouped all the scale items as we predicted. Furthermore, CFA were used to estimate the measurement models. Overall, the models indicated an acceptable fit: SCCs $(\mathrm{IFI}=.98, \mathrm{CFI}=.98, \mathrm{TLI}=.97, \mathrm{RMSEA}=.04), \mathrm{GO}(\mathrm{IFI}=.95, \mathrm{CFI}$ $=.95, \mathrm{TLI}=.93, \mathrm{RMSEA}=.07)$, and $\mathrm{EP}(\mathrm{IFI}=.99, \mathrm{CFI}=.99, \mathrm{TLI}=.98, \mathrm{RMSEA}=.07)$. All factor loadings were highly significant $(\mathrm{p}<.001)$, the composite reliability $(\mathrm{CR})$ of all constructs exceeded the .70 cutoff, and the average variance extracted (AVE) indices were greater than the .50 benchmark (Hair et al., 2010) (see Appendix). All of these results demonstrated adequate convergent validity and reliability. We compared the AVE for the individual constructs with the shared variance between all possible pairs of constructs. The results revealed that for each 
construct, the AVE was much higher than its maximum shared variance (MSV) with other constructs, thus supporting discriminant validity (Hair et al., 2010).

\subsection{Data analysis}

We applied hierarchical linear regression analyses to test our hypotheses, as employed in previous operations management research (e.g., Zhu and Sarkis, 2004). Prior to creating the interaction terms, we mean-centered the main effects and the moderator variable, as recommended by Aiken and West (1991). We also checked for possible collinearity problems by inspecting variance inflation factors (VIF). No significant VIF was found in any equations (VIF $<3.37$ ), suggesting that multicollinearity was not a major issue (Hair et al., 2010).

\section{Results}

\subsection{Regression results}

The descriptive statistical results and Pearson correlations are shown in Table 5.

Table 5 Descriptive Statistics and Correlations

\begin{tabular}{|c|c|c|c|c|c|c|c|c|c|c|c|c|c|c|c|}
\hline & Mean & $\overline{\text { s.d. }}$ & 1 & 2 & 3 & 4 & 5 & 6 & 7 & 8 & 9 & 10 & 11 & 12 & 13 \\
\hline 1. SIZE & 4.27 & 1.89 & 1 & & & & & & & & & & & & \\
\hline 2. OEM & 0.28 & 0.45 & $.28^{* *}$ & 1 & & & & & & & & & & & \\
\hline 3. Tier 1 & 0.52 & 0.50 & -.08 & $-.66^{* *}$ & 1 & & & & & & & & & & \\
\hline 4. INTER & 4.17 & 0.60 & $.14^{*}$ & -.04 & .09 & 1 & & & & & & & & & \\
\hline 5. APRSL & 4.12 & 0.70 & $.23^{* *}$ & -.10 & $.13^{*}$ & $.44^{* *}$ & 1 & & & & & & & & \\
\hline 6. EXTER & 3.93 & 0.69 & $.16^{*}$ & -.03 & .08 & $.47^{* * *}$ & $.58^{* *}$ & 1 & & & & & & & \\
\hline 7. SKILL & 3.88 & 0.62 & $.26^{* *}$ & -.01 & .12 & $.39^{* *}$ & $.37^{* *}$ & $.49^{* *}$ & 1 & & & & & & \\
\hline 8. FLEXY & 3.86 & 0.68 & $.17^{*}$ & -.08 & $.13^{*}$ & $.29^{* *}$ & $.33^{* *}$ & $.40^{* *}$ & $.49^{* *}$ & 1 & & & & & \\
\hline 9. IT/IS & 3.74 & 0.83 & .11 & $-.22^{* *}$ & $.16^{*}$ & $.42^{* *}$ & $.41^{* * *}$ & $.43^{* *}$ & $.44^{* * *}$ & $.36^{* *}$ & 1 & & & & \\
\hline 10. GD & 3.96 & 0.81 & $.41^{* *}$ & .10 & .02 & $.20^{* *}$ & $.30^{* *}$ & $.23^{* *}$ & $.36^{* *}$ & $.26^{* *}$ & $.16^{*}$ & 1 & & & \\
\hline 11. GP & 3.59 & 0.84 & $.35^{* *}$ & .01 & .05 & $.36^{* *}$ & $.44^{* *}$ & $.42^{* *}$ & $.39^{* *}$ & $.31^{* *}$ & $.33^{* *}$ & $.54^{* *}$ & 1 & & \\
\hline 12. GM & 4.00 & 0.78 & $.38^{* *}$ & .13 & .05 & $.27^{* *}$ & $.20^{* * *}$ & $.15^{*}$ & $.32^{* * *}$ & $.29^{* *}$ & .12 & $.55^{* *}$ & $.54^{* *}$ & 1 & \\
\hline 13. EP & 3.99 & 0.62 & $.15^{*}$ & $.19^{* *}$ & -.07 & $.28^{* *}$ & $.28^{* *}$ & $.28^{* *}$ & $.37^{* * *}$ & $.19^{* *}$ & .13 & $36^{* *}$ & $.37^{* *}$ & $.38^{* * *}$ & 1 \\
\hline
\end{tabular}

Table 6 shows the regression results. As revealed, firm size had significant positive effects on all of the DVs. In addition, OEM and Tier-1 suppliers only demonstrated significant positive 
associations with green manufacturing.

We found significant positive main effects of SCCs on GO strategies. As shown in Model 2 in Table 6, APRSL and SKILL were found to be significantly and positively related to GD, thus supporting H1. The results also revealed significant positive effects of APRSL and EXTER on GP, providing support for H2. INTER, SKILL, and FLEXY were found to have significant and positive associations with GM, confirming $\mathrm{H} 3$. Overall, $\mathrm{H} 1$ to $\mathrm{H} 3$ are partially supported.

The results for the moderating effects of EP were unexpected and mixed. First, no significant positive moderations were detected in Model 4 for GD. Surprisingly, it was found that EP negatively moderated the effect of FLEXY on GD. Turning to GP, similarly, EP was found to negatively moderate the effects of both INTER and FLEXY on GP. The results indicated a significant and positive moderating effect on the relationship between APRSL and GM. However, EP also revealed a negative moderation effect on the association between FLEXY and GM.

\subsection{Post-hoc analysis}

Considering that the multiple regression method may not fully utilize all the richness of our data, we further applied the partial least squares (PLS) approach using SmartPLS 3 to simultaneously assess the hypothesized model to enhance the robustness of our findings (Ringle et al., 2015). PLS includes all of the variance (common, unique, and error) that the exogenous variables have in common with the endogenous variables in estimating the model relationships (Sarstedt et al., 2016). The additional analyzing method can enhance our understanding of the data, the underlying structure among various constructs, and their relations. We also used bootstrapping technique with 5000 samples to test the significance levels of our hypotheses (Hair et al., 2011). 
Compared to our regression results, INTER demonstrated a marginal significant effect on GP ( $\beta$ $=0.12, \mathrm{p}<.10)$ and EP positively moderated the EXTER - GP linkage $(\beta=0.19, \mathrm{p}<.05)$ in the PLS test. Despite these marginal differences, the results from the PLS test have largely confirmed the regression results, thus enhancing the robustness of our findings. We believe that the application of the PLS approach with a bootstrapping algorithm provides higher and possibly more accurate path estimates (Chin et al., 2003; Hair et al., 2011).

\section{Discussion}

\subsection{Main effects}

In this study, we try to address the question of whether the successful implementation of GO strategies requires the support of specific logistics/SCM-related capabilities. We hypothesized that all six SCCs would be positively related to the GO strategies. However, the statistical results reveal a different story. For instance, supplier appraisal and SCM skills/knowledge are more important than the other SCCs for green design. This finding is closely in line with previous research that indicates suppliers today are playing a more important role in the focal firm's product development (Oh and Rhee, 2010). Therefore, a strong supplier appraisal capability coupled with an adequate level of SCM skills/knowledge can help the focal firms find competent suppliers and components to meet their green design requirements and criteria, thus facilitating the successful adoption of a green design strategy.

Supplier appraisal, internal and external integration also demonstrate significant positive associations with green purchasing. This finding is consistent with previous research (e.g., Noci, 1997; Sarkis and Dhavale, 2015), as a strong supplier appraisal capability can ensure that suppliers meet and satisfy the environmental criteria imposed by the buying firms. Contradictory 
Table 6 Regression Results

\begin{tabular}{|c|c|c|c|c|c|c|c|c|c|c|c|c|}
\hline \multirow[t]{2}{*}{ Variables entered } & \multicolumn{4}{|c|}{ Green design } & \multicolumn{4}{|c|}{ Green purchasing } & \multicolumn{4}{|c|}{ Green manufacturing } \\
\hline & Model 1 & Model 2 & Model 3 & Model 4 & Model 1 & Model 2 & Model 3 & Model 4 & Model 1 & Model 2 & Model 3 & Model 4 \\
\hline Intercept & $3.14 * * *$ & $3.36^{* * *}$ & $3.37 * * *$ & $3.43 * * *$ & $2.91 * * *$ & $3.19 * * *$ & $3.19 * * *$ & $3.24 * * *$ & $3.18 * * *$ & $3.36 * * *$ & $3.37 * * *$ & $3.42 * * *$ \\
\hline \multicolumn{13}{|l|}{ Control variables } \\
\hline Firm size & $.18 * *$ & $.13 * * *$ & $.14 * * *$ & $.13 * * *$ & $.16^{* * *}$ & $.10 * * *$ & $.11 * * *$ & $.10 * * *$ & $.14 * * *$ & $.11^{* * *}$ & $.12 * * *$ & $.11 * * *$ \\
\hline OEM & .06 & .08 & .00 & -.04 & -.14 & -.05 & -.11 & $-.16^{+}$ & $.24^{+}$ & .24 & .15 & .09 \\
\hline Tier 1 & .11 & .04 & .03 & .00 & .04 & -.04 & -.05 & -.06 & $.26^{*}$ & .19 & .18 & .15 \\
\hline \multicolumn{13}{|l|}{ Main effects } \\
\hline INTER & & .01 & -.03 & .01 & & .15 & .11 & $.17^{+}$ & & $.23 *$ & $.19 *$ & $.23 * *$ \\
\hline APRSL & & $.19^{*}$ & $.14^{+}$ & $.16^{+}$ & & $.21 *$ & $.17^{+}$ & $.15^{+}$ & & .04 & -.01 & .01 \\
\hline EXTER & & -.04 & -.05 & -.04 & & $.17^{+}$ & $.16^{+}$ & $.17^{+}$ & & -.14 & $-.15^{+}$ & $-.15^{+}$ \\
\hline SKILL & & $.29 * *$ & $.21 *$ & $.21 *$ & & .14 & .07 & .05 & & $.21 *$ & .12 & .11 \\
\hline FLEXY & & .09 & .09 & .09 & & .06 & .06 & .10 & & $.19^{*}$ & $.19^{*}$ & $.21 * *$ \\
\hline IT/IS & & -.05 & -.02 & .00 & & .07 & .09 & .05 & & -.06 & -.04 & -.05 \\
\hline \multicolumn{13}{|l|}{ Moderator } \\
\hline EP & & & $.30 * * *$ & $.33 * * *$ & & & $.26 * *$ & $.27 * *$ & & & $.32 * * *$ & $.37 * * *$ \\
\hline \multicolumn{13}{|l|}{ Interaction effects } \\
\hline $\mathrm{EP} \times \mathrm{INTER}$ & & & & .07 & & & & $-.35^{*}$ & & & & -.11 \\
\hline $\mathrm{EP} \times \mathrm{APRSL}$ & & & & .05 & & & & .04 & & & & $.27 *$ \\
\hline $\mathrm{EP} \times \mathrm{EXTER}$ & & & & .19 & & & & .18 & & & & .06 \\
\hline $\mathrm{EP} \times \mathrm{SKILL}$ & & & & -.10 & & & & .05 & & & & .06 \\
\hline $\mathrm{EP} \times \mathrm{FLEXY}$ & & & & $-.26^{*}$ & & & & $-.28 *$ & & & & $-.34 * *$ \\
\hline $\mathrm{EP} \times \mathrm{IT} / \mathrm{IS}$ & & & & .01 & & & & .16 & & & & -.02 \\
\hline$R^{2}$ & .17 & .27 & .31 & .34 & .13 & .33 & .36 & .39 & .16 & .26 & .31 & .35 \\
\hline$\Delta R^{2}$ & .17 & .09 & .04 & .03 & .13 & .20 & .03 & .03 & .16 & .10 & .05 & .04 \\
\hline$\Delta F$-stat & $15.48^{* * *}$ & $4.52 * * *$ & $12.88^{* * *}$ & 1.42 & $10.82 * * *$ & $10.81 * * *$ & $9.82 * *$ & 1.66 & $13.96 * * *$ & $4.60 * * *$ & $16.10^{* * *}$ & $2.31 *$ \\
\hline Durbin-Watson-stat & & & 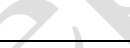 & 2.09 & & & & 1.87 & & & & 1.77 \\
\hline
\end{tabular}

Notes: Main table contains unstandardized coefficients.

${ }_{\mathrm{p}} \leq .10 ; \quad * \mathrm{p} \leq .05 ; \quad * * \mathrm{p} \leq .01 \quad * * * \mathrm{p} \leq .001$ 
to the work of Bowen et al. (2001), external integration could also facilitate green purchasing, which confirms the findings of other studies (e.g., Carter and Carter, 1998; Simpson et al., 2007; Zhu et al., 2010), as effective internal coordination and external collaborative partnerships could bring mutual environmental benefits through effective environmental cooperation, know-know, and technologies exchange.

Compared with other SCCs, internal integration, SCM skills/knowledge, and supply chain flexibility capabilities reveal stronger relationships with green manufacturing. Consistent with prior research (e.g., Klassen and Whybark, 1999; Vachon and Klassen, 2008), strong internal collaboration is required to deal with the complexity and challenges inherent in green manufacturing and achieve intended performance goals. Organizations may find it easier to introduce green technologies and novel processes in their plants when the logistics/supply chain department could bring on-board their skills and know-how. The finding of the positive association between supply chain flexibility and green manufacturing may offer support for the work of Klassen and Angell (1998), in which they found that manufacturing flexibility might enable the scope and depth of integrating environmental issues into manufacturing.

In contrast, other SCCs do not reveal a strong or significant relationship with the specific GO strategies we studied. For instance, IT/IS capability is not significantly correlated with any GO strategy. A possible explanation might be that although IT/IS capability can facilitate information gathering, sharing, and monitoring, it is not a vital determinant for a successful green strategy adoption. In other words, IT/IS capability could be a good "supporter" but is not a significant "enabler". Furthermore, the discovery of strong effects of internal integration on green manufacturing and external integration on green purchasing may provide additional support for Mackelprang et al.'s (2014) meta-analysis of supply chain integration and 
performance, in which they argued that internal integration tends to be associated with more firm-centric outcomes than supply chain-centric outcomes, while external integration tends to relate more strongly to supply chain-centric outcomes than to firm-centric outcomes.


Figure 2 Moderating effects of EP 


\subsection{Moderating effects}

The main focus of our study is on the more interesting moderating effects, i.e., whether the relationships between SCCs and GO strategies are contingent on certain organizing contexts. In hypothesis 4, we posited that a high level of EP would positively moderate the effects of SCCs on the implementation of GO strategies. However, our findings are quite unexpected.

We conducted a supplementary analysis by plotting two-way interaction effects, as shown in Figure 2. This technique enabled us to identify the statistical significance of the effects of SCCs on GO strategies at two levels of EP (the moderator).

The first positive moderation of EP is found in the external integration - green purchasing link (see Figure 2c). A possible explanation for this finding may be that the environmentally proactive firms focus more on external collaboration and establish strategic partnerships with their suppliers for environmental objectives. The strategic partnerships could facilitate supplier development in green purchasing, which could bring more environmental benefits than simply selecting and switching to new suppliers who can meet the focal firms' environmental requirements. This finding may reinforce Blome et al.'s (2014) work, in which they noted that external collaboration that focusing on green supplier development is strategically important for achieving a successful green procurement initiative.

Another positive moderation is discovered in the association between supplier appraisal and green manufacturing (see Figure 2e). That is, supplier appraisal capability best facilitates the implementation of green manufacturing strategies in more environmentally proactive firms. To a certain extent, this finding reveals the critical role of suppliers in the adoption of green manufacturing within the focal buying organizations. This finding is closely in line with previous 
studies on the significance of suppliers' capabilities in environmental management. For example, Wong et al. (2012) demonstrated that the environmental management capabilities of suppliers could significantly influence the successful adoption of GO strategies within the buying firms. Environmentally proactive organizations may be more likely to deploy and exploit their supplier appraisal capabilities to ensure that their suppliers have the necessary resources and capabilities to facilitate their own green manufacturing initiatives. Thus, the relationship between supplier appraisal capability and green manufacturing becomes stronger in more environmentally proactive firms.

Next, we attempt to seek explanations for the negative moderating effects. However, the reasons for these counterintuitive negative effects are complicated and raise significant questions in our analysis. In other words, do these findings actually suggest that the more environmentally proactive firms are less likely to deploy their SCCs for GO strategy implementation? Could there perhaps be some other underlying reasons for the weakened relationships? By checking the interaction effects in Figure 2 and the main effects of EP in Model 3 for each GO strategy in Table 6 , we can confidently conclude that more environmentally proactive firms are more likely to successfully implement the three GO strategies. To develop a better understanding of the potential causes of the negative moderating effects, we conducted five post-survey interviews with senior managers who participated in our survey. For brevity's sake, only the relevant findings are discussed here.

First, as shown in Figure 2b, firms with a high level of EP still demonstrate a high degree of green purchasing implementation, regardless of whether they have a low or high level of internal integration. As revealed in the interviews, one possible explanation for the weakened relationship between internal integration and green purchasing is that environmentally proactive auto firms 
often establish more specialized and dedicated purchasing teams to lead and monitor their green purchasing implementation. While cross-functional collaboration and the involvement of the logistic/SCM department in green purchasing may bring some benefits, their influence becomes increasingly less obvious and significant in this relationship. This is especially true when the buying firms become more environmentally proactive, and thus green purchasing becomes more mature, specialized, and complex. This finding, to a certain extent, is consistent with the view of Mackelprang et al. (2014), who argued that the integration - performance relationships are not always significant and can be subjected to unknown moderating factors. In our case, it is the organizing context of corporate EP that affects the internal integration - green purchasing relationship.

Surprisingly, the effects of supply chain flexibility on green design, green purchasing, and green manufacturing are consistently weaker in more proactive firms (see Figure 2a, 2d, and 2f). As the results reveal, more environmentally proactive firms are associated with a higher degree of GO strategy implementation (or in the later stage of a successful implementation, as reflected in our measures). Supply chain flexibility may be required more during the early stage of the implementation (e.g., the evaluation and planning stage), thus representing a stronger relationship. For example, green design may need alternative materials, thus requiring flexible sourcing; green purchasing may require suppliers to have environmental certifications, thus necessitating flexibility in the selection of alternative suppliers; and green manufacturing may need to change the existing production processes (e.g., lean production), thus requiring fast and flexible deliveries.

However, in the later stage of the implementation (e.g., the implementation and finalization stages), supply chain flexibility perhaps plays a less important role than in the early stages. This 
may be because once the alternative materials and suppliers are evaluated and confirmed, the buying firms may concentrate on launching their green products, strengthening their ties and collaborations with the new suppliers, and optimizing their production process for their lean production. Therefore, the relationships between supply chain flexibility and GO strategies are weakened in those more environmentally proactive firms. We argue that, in the later stage of GO strategy implementation, or if the focal firms want to achieve a more successful GO strategy implementation, they need to carefully manage or deploy their supply chain flexibility in order to maximize their green efforts. This finding, to some extent, is supported by Vachon and Klassen (2006), who asserted that too much supply chain flexibility might even cause adverse effects on active environmental collaboration such as frequent partnership changes and/or supply base increases.

This finding is also reinforced by our post-survey interviews. As one manager put it, “...flexibility is important when it comes to sourcing, but you can't always switch your suppliers! It is quite costly..." In more environmentally proactive auto firms, a lean-side capability that focuses on efficiency, optimization, and waste reduction was more favorable for such firms' environmental management. When actively pursuing their environmental goals, these organizations made greater efforts to develop and strengthen their lean-side capabilities than their supply chain flexibility when actively pursuing their environmental goals. This could possibly explain why, in the advanced stage of implementation, supply chain flexibility demonstrates almost no impact on green manufacturing, as depicted in Figure 2e.

\subsection{Theoretical implications}

The recent reviews of empirical research on the RBV of the firm suggest that the capability strategy linkage has largely been neglected in the literature, as the majority of research has 
focused on the capability - performance/competitive advantage link (Armstrong and Shimizu, 2007; Newbert, 2007). This may be because that the capability - strategy linkage seems fairly obvious, and therefore filling this void is considered uninteresting. However, none of the previous studies, including Bowen et al. (2001), helps us understand how specific logistics/SCMrelated capabilities could support the adoption of green strategies. For instance, no significant relationship was revealed between supply management capability and "greening the supply process" in Bowen et al.'s (2001) study, where internal and external integration were the key dimensions of their supply management capability construct. In contrast, Carter and Carter (1998) found significant positive effects of internal collaboration and increased coordination with suppliers on the successful adoption of green purchasing initiatives.

Our research findings may provide useful insights into this important capability - strategy linkage by addressing the specific roles of SCCs in the adoption of GO strategies. Although our hypotheses are not fully supported, the study reveals that specific GO strategies may require the support of specific SCCs - therefore addressing the strategic "fit" between them (Lynch et al., 2000). The study's findings regarding the impacts of internal and external integration on green manufacturing and green purchasing, respectively, further confirm the findings of previous studies on the divergent effects of supply chain integration on firm performance under special circumstances (Mackelprant et al., 2014).

In addition, this study provides a more nuanced understanding of the moderating role of EP in the capability - strategy link. Contradictory to our initial hypotheses, EP not only can enhance certain SCCs - GO strategy linkages, but can also weaken some of these associations. The discovery of the moderation effects of EP further confirms the important influence of firm-level conditions (Newbert, 2007; Lin and Ho, 2011) on the effective exploitation of resources and 
capabilities for obtaining a competitive advantage. Moreover, the consistent negative moderation effects of EP on supply chain flexibility and the three GO strategies may offer useful insights regarding the debate on whether lean is green, given the close association between supply chain flexibility and agility (King and Lenox, 2001; Rothenberg et al., 2001).

\subsection{Practical implications}

In practice, the adoption of green strategies is often a complex and challenging task. Managers should take care to consider whether the GO strategies they want to follow "fit" with their existing SCCs. Furthermore, they should strategically develop and deploy appropriate SCCs for specific green strategy implementation. For example, for a green purchasing strategy, firms may want to develop and strengthen their supplier appraisal, internal and external integration capabilities, whereas for green manufacturing, they may want to pay more attention to their internal integration and SCM skills/knowledge capabilities.

When a firm follows a more proactive environmental stance, greater managerial awareness (especially at the top rung) regarding which SCCs can boost the success rate of specific GO strategies may benefit the firm by improving the effectiveness and efficiency of its resource and capability deployment. Taking supply chain flexibility as an example, a strategy to consider could be actively coordinating and engaging strategic suppliers for green design, green purchasing, and green manufacturing initiatives, while simultaneously maintaining an appropriate level of supply chain flexibility (e.g., a reasonable supply base).

Moreover, firms seeking environment-related competitive advantages will need to possess certain capabilities as a prerequisite condition. However, simply possessing these capabilities may not automatically lead to the expected competitive outcome; instead, gaining the 
environment-related competitive advantages depends on how a firm can effectively deploy and exploit the right capabilities for specific GO strategies.

\section{Conclusion}

Drawing on the theoretical models of RBV, this study argues that the adoption of GO strategies requires the development and deployment of specific SCCs. Using evidence from the global automotive sector, this study adds to our understanding of the capability - strategy linkage and its specific application to environmental management. Most importantly, our introduction of EP as a crucial moderating construct in the linkage between SCCs and GO strategies distinguishes our contribution from previous research. The findings of the study provide further empirical validation of the importance of firm-level conditions in the effective exploitation of resources and capabilities for securing a competitive advantage.

Despite these contributions, our study has several limitations. First, we only collected data from the automotive industry, which may affect generalizability beyond this sector. Second, our study only focused on three key GO areas, neglecting, for example, green logistics. Third, we only used a few items to measure supply chain flexibility on a rather integrated level. Although the findings may provide useful insights into GO strategy implementation, our study may not be able to depict the accurate effects of supply chain flexibility on GO because of the multidimensional nature of this construct. This represents both a limitation and an opportunity for further study. Fourth, the results of the study could be affected by common-method bias due to the selfreported data collection. A final limitation was that only cross-sectional data were used for the study. The use of longitudinal data would extend the scope of the findings beyond inferences of association to inferences of causality. 
Though the present study has several limitations, the findings have important implications for both theory and practice. Future studies that test the robustness of the present work and its extension should be encouraged, for example, to compare and contrast the regional differences between the Chinese and non-Chinese firms.

\section{Acknowledgement}

We wish to thank the Editor Prof B. MacCarthy, and three anonymous reviewers for their helpful and constructive comments for the improvement of our manuscript. This work is supported by two projects funded by the National Natural Science Foundation of China (71632007 and $71472021)$. 


\section{Appendix: Measurement Items, Reliability and Validity Test}

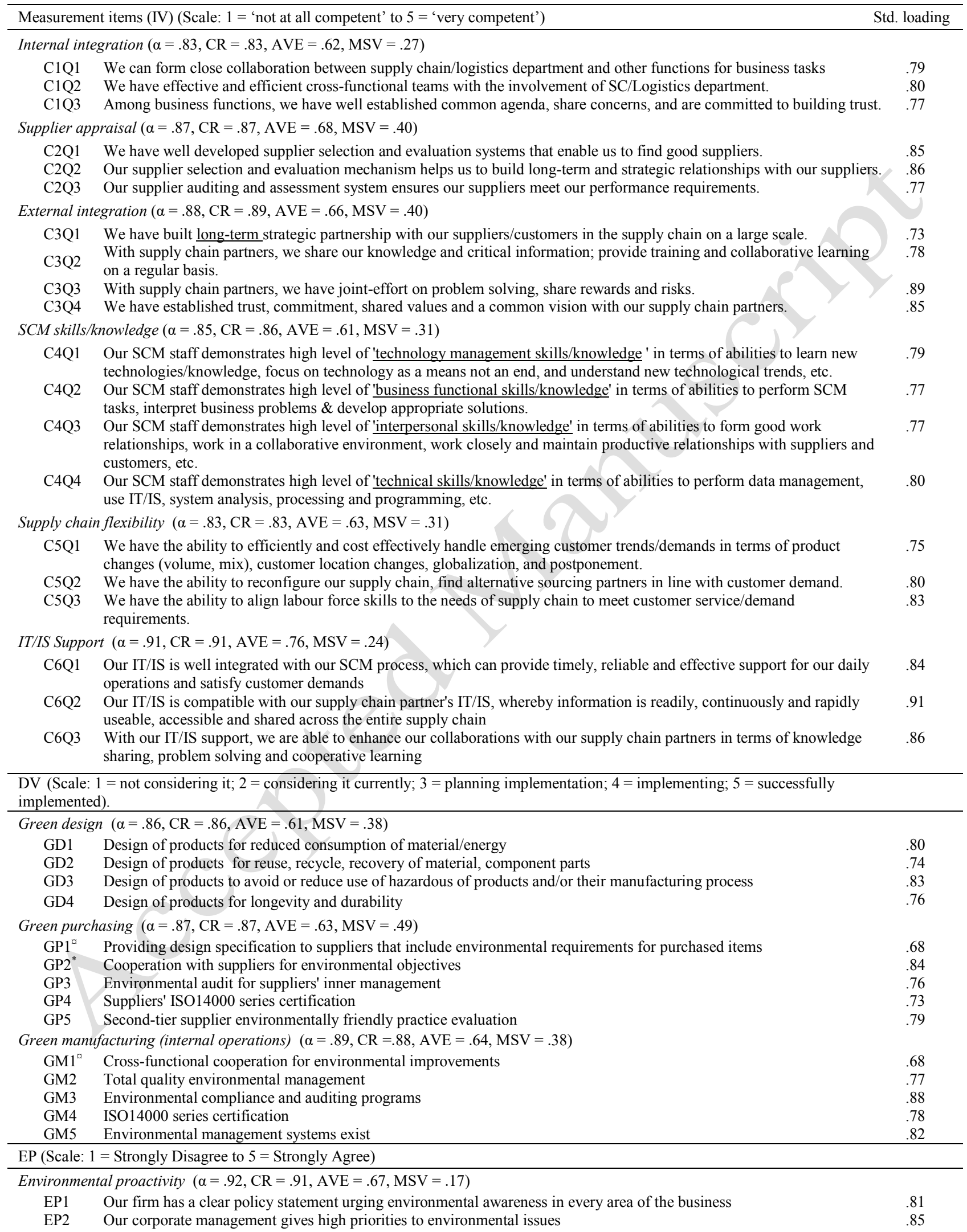


We always attempt to go beyond basic compliance with laws and regulations on environmental issues

Protecting the environment is a central corporate value in our firm

Top management commits to sustainable environmental development

We lead our industry on environmental management

Note: *Items were retained in the survey, though they seem to overlap with our IV: external integration. We believed that only the firms possessing this capability were able to collaborate with external partners for environmental objectives. ${ }^{\text {a }}$ Item was dropped in CFA;

\section{References}

Aiken, L.S., West, S.G., 1991. Multiple regression: Testing and interpreting interactions. Sage, Thousand Oaks, CA.

Aragón-Correa, J.A., Sharma, S., 2003. A contingent resource-based view of proactive corporate environmental strategy. The Academy of Management Review 28, 71-88.

Armstrong, C.E., Shimizu, K., 2007. A Review of Approaches to Empirical Research on the Resource-Based View of the Firm. Journal of Management 33, 959-986.

Armstrong, J., Overton, T., 1977. Estimating nonresponse bias in mail surveys. Journal of Marketing Research 14, 396-402.

Barney, J., 1991. Firm resources and sustained competitive advantage. Journal of Management 17, 99-120.

Beske, P., Land, A., Seuring, S., 2014. Sustainable supply chain management practices and dynamic capabilities in the food industry: A critical analysis of the literature. International Journal of Production Economics 152, 131-143.

Bharadwaj, S., Bharadwaj, A., Bendoly, E., 2007. The performance effects of complementarities between information systems, marketing, manufacturing, and supply chain processes. Information Systems Research 18, 437-453.

Blome, C., Hollos, D., Paulraj, A., 2014. Green procurement and green supplier development: antecedents and effects on supplier performance. International Journal of Production Research $52,32-49$.

Bowen, F.E., Cousins, P.D., Lamming, R.C., Faruk, A.C., 2001. The role of supply management capabilities in green supply. Production and Operations Management 10, 174-189.

Briscoe, G., Dainty, A.R.J., Millett, S., 2001. Construction supply chain partnerships: skills, knowledge and attitudinal requirements. European Journal of Purchasing \& Supply Management 7, 243-255.

Byrd, T.A., Turner, D.E., 2001. An exploratory analysis of the value of the skills of IT personnel: Their relationship to IS infrastructure and competitive advantage. Decision Sciences 32, 21-54.

Cao, M., Zhang, Q., 2011. Supply chain collaboration: impact on collaborative advantage and firm performance. Journal of Operations Management 29, 163-180.

Carter, C.R., Carter, J.R., 1998. Interorganizational Determinants of Environmental Purchasing: Initial Evidence from the Consumer Products Industries*. Decision Sciences 29, 659-684.

Chin, W.W., Marcolin, B.L., Newsted, P.R., 2003. A partial least squares latent variable modeling approach for measuring interaction effects: Results from a Monte Carlo simulation study and an electronic-mail emotion/adoption study. Information systems research 14, 189217.

Choi, T.Y., Hartley, J.L., 1996. An exploration of supplier selection practices across the supply chain. Journal of Operations Management 14, 333-343. 
Cousins, P.D., Menguc, B., 2006. The implications of socialization and integration in supply chain management. Journal of Operations Management 24, 604-620.

Das, A., Narasimhan, R., Talluri, S., 2006. Supplier integration-finding an optimal configuration. Journal of Operations Management 24, 563-582.

Daugherty, P.J., Chen, H., Mattioda, D.D., Grawe, S.J., 2009. Marketing/logistics relationships: influence on capabilities and performance. Journal of Business Logistics 30, 1-18.

Defee, C.C., Fugate, B.S., 2010. Changing perspective of capabilities in the dynamic supply chain era. International Journal of Logistics Management, The 21, 180-206.

Deif, A.M., 2011. A system model for green manufacturing. Journal of Cleaner Production 19, 1553-1559.

Duclos, L.K., Vokurka, R.J., Lummus, R.R., 2003. A conceptual model of supply chain flexibility. Industrial Management \& Data Systems 103, 446-456.

Emmett, S., Sood, V., 2010. Green Supply Chains: An Action Manifesto. John Wiley \& Sons, Ltd, West Sussex.

Eng, T.Y., 2005. The Influence of a Firm's Cross-Functional Orientation on Supply Chain Performance. Journal of Supply Chain Management 41, 4-16.

Esper, T.L., Fugate, B.S., Davis-Sramek, B., 2007. Logistics learning capability: sustaining the competitive advantage gained through logistics leverage. Journal of Business Logistics 28, $57-82$.

Fawcett, S.E., Stanley, L.L., Smith, S.R., 1997. Developing a logistics capability to improve the performance of international operations. Journal of Business Logistics 18, 101-127.

Fawcett, S.E., Wallin, C., Allred, C., Fawcett, A.M., Magnan, G.M., 2011. Information technology as an enabler of supply chain collaboration: a dynamic-capabilities perspective. Journal of Supply Chain Management 47, 38-59.

Figge, F., Hahn, T., 2012. Is green and profitable sustainable? Assessing the trade-off between economic and environmental aspects. International Journal of Production Economics 140, 92 102.

Flynn, B.B., Huo, B., Zhao, X., 2010. The impact of supply chain integration on performance: A contingency and configuration approach. Journal of Operations Management 28, 58-71.

Ford, 2014. Creating a Sustainable Supply Chain: Ford's Overall Approach. Available at: http://corporate.ford.com/microsites/sustainability-report-2013-14/supply-creating.html (accessed 22 Feb 2016).

Fowler, F.J., 2009. Survey research methods, 4th ed. Sage, Thousand Oaks, CA.

Gavronski, I., Klassen, R.D., Vachon, S., do Nascimento, L.F.M., 2012. A learning and knowledge approach to sustainable operations. International Journal of Production Economics 140, 183-192.

Gimenez, C., Sierra, V., Rodon, J., 2012. Sustainable operations: Their impact on the triple bottom line. International Journal of Production Economics 140, 149-159.

Glantschnig, W.J., 1994. Green design: an introduction to issues and challenges. IEEE Transactions on Components, Packaging, and Manufacturing Technology-Part A 17, 508513.

Gligor, D.M., Holcomb, M.C., 2012. Understanding the role of logistics capabilities in achieving supply chain agility: a systematic literature review. Supply Chain Management: An International Journal 17, 438-453.

Gmelin, H., Seuring, S., 2014. Achieving sustainable new product development by integrating product life-cycle management capabilities. International Journal of Production Economics 
$154,166-177$.

Gold, S., Seuring, S., Beske, P., 2010. Sustainable supply chain management and inter organizational resources: a literature review. Corporate Social Responsibility and Environmental Management 17, 230-245.

González-Benito, J., González-Benito, Ó., 2005. Environmental proactivity and business performance: an empirical analysis. Omega 33, 1-15.

Green, K., Morton, B., New, S., 1996. Purchasing and environmental management: interactions, policies and opportunities. Business Strategy and the Environment 5, 188-197.

Hair, J.F., Black, W.C., Babin, B.J., Anderson, R.E., 2010. Multivariate Data Analysis A Global Perspective, 7th ed. Pearson Education, New Jersey.

Hair, J.F., Ringle, C.M., Sarstedt, M., 2011. PLS-SEM: Indeed a Silver Bullet. The Journal of Marketing Theory and Practice 19, 139-152.

Handfield, R., Sroufe, R., Walton, S., 2005. Integrating environmental management and supply chain strategies. Business Strategy and the Environment 14, 1-19.

Handfield, R.B., Melnyk, S.A., Calantone, R.J., Curkovic, S., 2001. Integrating environmental concerns into the design process: the gap between theory and practice. Engineering Management, IEEE Transactions on 48, 189-208.

Handfield, R.B., Walton, S.V., Seegers, L.K., Melnyk, S.A., 1997. “Green”value chain practices in the furniture industry. Journal of Operations Management 15, 293-315.

Jassawalla, A.R., Sashittal, H.C., 1999. Building collaborative cross-functional new product teams. The Academy of Management Executive (1993-2005) 13, 50-63.

Kannan, V.R., Tan, K.C., 2002. Supplier selection and assessment: Their impact on business performance. Journal of Supply Chain Management 38, 11-21.

Kim, S.W., 2006. The effect of supply chain integration on the alignment between corporate competitive capability and supply chain operational capability. International Journal of Operations \& Production Management 26, 1084-1107.

King, A.A., Lenox, M.J., 2001. Lean and green? An empirical examination of the relationship between lean production and environmental performance. Production and Operations Management 10, 244-256.

Klassen, R.D., 1993. The integration of environmental issues into manufacturing. Toward an interactive open-systems model. Production and Inventory Management Journal 34, 82-88.

Klassen, R.D., Angell, L.C., 1998. An international comparison of environmental management in operations: the impact of manufacturing flexibility in the US and Germany. Journal of Operations Management 16, 177-194.

Klassen, R.D., Johnson, P.F., 2004. The green supply chain. In: New, S.J., Westbrook, R., (Eds). Understanding Supply Chains: Concepts, Critiques, and Futures. Oxford University Press, 229-251.

Klassen, R.D., Vachon, S., 2003. Collaboration and evaluation in the supply chain: The impact on plant-level environmental investment. Production and Operations Management 12, 336352.

Klassen, R.D., Whybark, D.C., 1999. The impact of environmental technologies on manufacturing performance. The Academy of Management Journal 42, 599-615.

Kogut, B., Zander, U., 1992. Knowledge of the firm, combinative capabilities, and the replication of technology. Organization Science 3, 383-397.

Kristal, M.M., Huang, X., Roth, A.V., 2010. The effect of an ambidextrous supply chain strategy on combinative competitive capabilities and business performance. Journal of Operations 
Management 28, 415-429.

Lado, A.A., Paulraj, A., Chen, I.J., 2011. Customer focus, supply-chain relational capabilities and performance: Evidence from US manufacturing industries. The International Journal of Logistics Management 22, 202-221.

Lee, A.H.., Kang, H.Y., Hsu, C.F., Hung, H.C., 2009. A green supplier selection model for hightech industry. Expert Systems with Applications 36, 7917-7927.

Lee, D.M.S., Trauth, E.M., Farwell, D., 1995. Critical skills and knowledge requirements of IS professionals: a joint academic/industry investigation. MIS Quarterly 19, 313-340.

Lee, J.Y., Swink, M., Pandejpong, T., 2011. The roles of worker expertise, information sharing quality, and psychological safety in manufacturing process innovation: An intellectual capital perspective. Production and Operations Management 20, 556-570.

Lee, S.-Y., Klassen, R.D., 2008. Drivers and Enablers That Foster Environmental Management Capabilities in Small-and Medium-Sized Suppliers in Supply Chains. Production and Operations Management 17, 573-586.

Lee, S.Y., Rhee, S.-K., 2007. The change in corporate environmental strategies: a longitudinal empirical study. Management Decision 45, 196-216.

Leuschner, R., Rogers, D.S., Charvet, F.F., 2013. A meta-analysis of supply chain integration and firm performance. Journal of Supply Chain Management 49, 34-57.

Lin, C.-Y., Ho, Y.-H., 2011. Determinants of green practice adoption for logistics companies in China. Journal of Business Ethics 98, 67-83.

Longoni, A., Golini, R., Cagliano, R., 2014. The role of New Forms of Work Organization in developing sustainability strategies in operations. International Journal of Production Economics 147, 147-160.

Lynch, D.F., Keller, S.B., Ozment, J., 2000. The effects of logistics capabilities and strategy on firm performance. Journal of Business Logistics 21, 47-67.

Mackelprang, A.W., Robinson, J.L., Bernardes, E., Webb, G.S., 2014. The Relationship Between Strategic Supply Chain Integration and Performance: A Meta-Analytic Evaluation and Implications for Supply Chain Management Research. Journal of Business Logistics 35, 7196.

Malhotra, M.K., Mackelprang, A.W., 2012. Are internal manufacturing and external supply chain flexibilities complementary capabilities? Journal of Operations Management 30, 180200.

Marchi, V.D., Maria, E.D., Micelli, S., 2013. Environmental Strategies, Upgrading and Competitive Advantage in Global Value Chains. Business Strategy and the Environment 22, 62-72.

Mazda, 2014. Mazda Sustainability Report 2014. Available at: http://www2.mazda.com/en/csr/download/pdf/2014/2014_s_all.pdf (accessed 10 January 2016).

Melville, N.P., 2010. Information systems innovation for environmental sustainability. MIS Quarterly 34, 1-21.

Miller, G., Pawloski, J., Standridge, C.R., 2010. A case study of lean, sustainable manufacturing. Journal of Industrial Engineering and Management 3, 11-32.

Min, H., Galle, W.P., 1997. Green purchasing strategies: trends and implications. Journal of Supply Chain Management 33, 10-17.

Modi, S.B., Mabert, V.A., 2007. Supplier development: improving supplier performance through knowledge transfer. Journal of Operations Management 25, 42-64. 
Morash, E.A., 2001. Supply chain strategies, capabilities, and performance. Transportation Journal 41, 37-54.

Newbert, S.L., 2007. Empirical research on the resource-based view of the firm: an assessment and suggestions for future research. Strategic Management Journal 28, 121-146.

Noci, G., 1997. Designing “green" vendor rating systems for the assessment of a supplier's environmental performance. European Journal of Purchasing \& Supply Management 3, 103114.

Nunes, B., Bennett, D., 2010. Green operations initiatives in the automotive industry: an environmental reports analysis and benchmarking study. Benchmarking: An International Journal 17, 396-420.

Nunnally, J., 1978. Psychometric theory. New York: McGraw-Hill.

Oh, J., Rhee, S.-K., 2010. Influences of supplier capabilities and collaboration in new car development on competitive advantage of carmakers. Management Decision 48, 756-774.

Olavarrieta, S., Ellinger, A.E., 1997. Resource-based theory and strategic logistics research. International Journal of Physical Distribution \& Logistics Management 27, 559-587.

Parmigiani, A., Klassen, R.D., Russo, M.V., 2011. Efficiency meets accountability: Performance implications of supply chain configuration, control, and capabilities. Journal of Operations Management 29, 212-223.

Podsakoff, P.M., MacKenzie, S.B., Lee, J.-Y., Podsakoff, N.P., 2003. Common method biases in behavioral research: a critical review of the literature and recommended remedies. Journal of Applied Psychology 88, 879-903.

PUMA, 2013. Business and Sustainability Report 2013. Available at: http://about.puma.com/en/sustainability/ (accessed 08 January 2016).

Rai, A., Patnayakuni, R., Seth, N., 2006. Firm performance impacts of digitally enabled supply chain integration capabilities. MIS Quarterly 30, 225-246.

Ralston, P.M., Grawe, S.J., Daugherty, P.J., 2013. Logistics salience impact on logistics capabilities and performance. International Journal of Logistics Management, The 24, 136152.

Rothenberg, S., Pil, F.K., Maxwell, J., 2001. Lean, green, and the quest for superior environmental performance. Production and Operations Management 10, 228-243.

Ringle, C. M., Wende, S., Becker, J.-M., 2015. SmartPLS 3. Boenningstedt: SmartPLS GmbH, http://www.smartpls.com.

Sánchez, A.M., Pérez, M.P., 2005. Supply chain flexibility and firm performance: a conceptual model and empirical study in the automotive industry. International Journal of Operations \& Production Management 25, 681-700.

Sanders, N.R., Premus, R., 2005. Modeling the relationship between firm IT capability, collaboration, and performance. Journal of Business Logistics 26, 1-23.

Sarkis, J., Dhavale, D.G., 2015. Supplier selection for sustainable operations: A triple-bottomline approach using a Bayesian framework. International Journal of Production Economics 166, 177-191.

Sarstedt, M., Hair, J.F., Ringle, C.M., Thiele, K.O., Gudergan, S.P., 2016. Estimation issues with PLS and CBSEM: Where the bias lies! Journal of Business Research 69, 3998-4010.

Schoenherr, T., Swink, M., 2012. Revisiting the arcs of integration: Cross-validations and extensions. Journal of Operations Management 30, 99-115.

Shang, K., Marlow, P.B., 2005. Logistics capability and performance in Taiwan's major manufacturing firms. Transportation Research Part E: Logistics and Transportation Review 


\section{1, 217-234.}

Shang, K.C., Lu, C.S., Li, S., 2010. A taxonomy of green supply chain management capability among electronics-related manufacturing firms in Taiwan. Journal of Environmental Management 91, 1218-1226.

Simpson, D., Power, D., Samson, D., 2007. Greening the automotive supply chain: a relationship perspective. International Journal of Operations \& Production Management 27, 28-48.

Spekman, R.E., 1988. Strategic supplier selection: understanding long-term buyer relationships. Business Horizons 31, 75-81.

Stank, T.P., Lackey, C.W., 1997. Enhancing performance through logistical capabilities in Mexican maquiladora firms. Journal of Business Logistics 18, 91-123.

Steenkamp, J.-B.E., Baumgartner, H., 1998. Assessing measurement invariance in cross-national consumer research. Journal of Consumer Research 25, 78-107.

Stevenson, M., Spring, M., 2007. Flexibility from a supply chain perspective: definition and review. International Journal of Operations \& Production Management 27, 685-713.

Takeishi, A., 2001. Bridging inter-and intra-firm boundaries: management of supplier involvement in automobile product development. Strategic Management Journal 22, 403-433.

Teece, D., Pisano, G., 1994. The dynamic capabilities of firms: an introduction. Industrial and Corporate Change 3, 537-556.

Thoumy, M., Vachon, S., 2012. Environmental projects and financial performance: Exploring the impact of project characteristics. International Journal of Production Economics 140, 28 34.

Thun, J.-H., Müller, A., 2010. An empirical analysis of green supply chain management in the German automotive industry. Business Strategy and the Environment 19, 119-132. doi:10.1002/bse.642

Tracey, M., Lim, J.S., Vonderembse, M.A., 2005. The impact of supply-chain management capabilities on business performance. Supply Chain Management: An International Journal 10, 179-191.

Tracey, M., Tan, C.L., 2001. Empirical analysis of supplier selection and involvement, customer satisfaction, and firm performance. Supply Chain Management: An International Journal 6, 174-188.

Unilever, 2014. Sustainable sourcing. Available at: http://www.unilever.co.uk/sustainable-living2014/sustainable-sourcing/ (accessed 10 January 2016).

Vachon, S., Klassen, R.D., 2008. Environmental management and manufacturing performance: The role of collaboration in the supply chain. International Journal of Production Economics 111, 299-315.

Vachon, S., Klassen, R.D., 2006. Extending green practices across the supply chain: the impact of upstream and downstream integration. International Journal of Operations \& Production Management 26, 795-821.

van Hoek, R.I., 2001. Case studies of greening the automotive supply chain through technology and operations. International Journal of Environmental Technology and Management 1, 140163.

Vickery, S., Calantone, R., Dröge, C., 1999. Supply chain flexibility: an empirical study. Journal of Supply Chain Management 35, 16-24.

Wernerfelt, B., 1984. A resource-based view of the firm. Strategic Management Journal 5, 171180.

Wong, C.W., Lai, K., Shang, K.-C., Lu, C.-S., Leung, T.K.P., 2012. Green operations and the 
moderating role of environmental management capability of suppliers on manufacturing firm performance. International Journal of Production Economics 140, 283-294.

Wu, F., Yeniyurt, S., Kim, D., Cavusgil, S.T., 2006. The impact of information technology on supply chain capabilities and firm performance: A resource-based view. Industrial Marketing Management 35, 493-504.

Wu, Z., Pagell, M., 2011. Balancing priorities: Decision-making in sustainable supply chain management. Journal of Operations Management 29, 577-590.

Xia, Y., Tang, T., Li-Ping, 2011. Sustainability in supply chain management: suggestions for the auto industry. Management Decision 49, 495-512.

Zhang, H.C., Kuo, T.C., Lu, H., Huang, S.H., 1997. Environmentally conscious design and manufacturing: a state-of-the-art survey. Journal of Manufacturing Systems 16, 352-371.

Zhang, Q., Vonderembse, M.A., Lim, J.-S., 2002. Value chain flexibility: a dichotomy of competence and capability. International Journal of Production Research 40, 561-583.

Zhao, M., Dröge, C., Stank, T.P., 2001. The effects of logistics capabilities on firm performance: customer-focused versus information-focused capabilities. Journal of Business Logistics 22, 91-107.

Zhao, X., Huo, B., Selen, W., Yeung, J.H.Y., 2011. The impact of internal integration and relationship commitment on external integration. Journal of Operations Management 29, 17 32.

Zhu, Q., Geng, Y., Tsuyoshi, F., Shizuka, H., 2010. Green supply chain management in leading manufacturers: case studies in Japanese large companies. Management Research Review 33, 380-392.

Zhu, Q., Sarkis, J., 2004. Relationships between operational practices and performance among early adopters of green supply chain management practices in Chinese manufacturing enterprises. Journal of Operations Management 22, 265-289.

Zhu, Q., Sarkis, J., Lai, K., 2008. Confirmation of a measurement model for green supply chain management practices implementation. International Journal of Production Economics 111, 261-273.

Zhu, Q., Sarkis, J., Lai, K., 2007. Green supply chain management: pressures, practices and performance within the Chinese automobile industry. Journal of Cleaner Production 15, 10411052 . 